\title{
Anthropogenic pressure indicators associated with vessel groundings on coral reefs in a marine protected area
}

\section{Indicadores de presión antropogénica asociados a encallamientos en arrecifes coralinos de un área marina protegida}

\author{
Sachiko Hayasaka-Ramírez, Leonardo Ortiz-Lozano* \\ Instituto de Ciencias Marinas y Pesquerías, Universidad Veracruzana, Av. Hidalgo no. 617, Col. Río Jamapa, \\ CP 94290 Boca del Río, Veracruz, México. \\ * Corresponding author. E-mail: ortizleo@gmail.com
}

\begin{abstract}
Historical information was collected on vessel groundings in the Parque Nacional Sistema Arrecifal Veracruzano (Veracruz Reef System National Park, PNSAV) during the periods 1902-1945 and 1970-2010 to generate specific pressure indicators associated with these events. Information on 126 vessel groundings was gathered, and the cause, specific location, season, and type of vessel were analyzed. Three indicators were generated: stranding pressure, annual pressure, and pressure per site. The highest number of vessel groundings occurred in 1925 and on the Anegada de Adentro reef, the most impacted in both periods. The most common causes of strandings were human error and northerly winds (Nortes). Small vessels were the ones that impacted the most against the reefs. The indicators showed that despite technological advances, pressure caused by groundings in PNSAV continues to occur at a medium level. These indicators are relevant for the management of the area in view of the imminent expansion of the port of Veracruz, which will likely lead to increased vessel traffic and a potential increase in vessel groundings.
\end{abstract}

Key words: vessel groundings, pressure indicators, coral reefs, marine protected areas, Sistema Arrecifal Veracruzano.

RESUMEN. Con el objetivo de generar indicadores específicos de presión asociados a eventos de encallamiento en el Parque Nacional Sistema Arrecifal Veracruzano (PNSAV), se realizó una búsqueda de información histórica referente a los eventos ocurridos entre los periodos 1902-1945 y 1970-2010. Se recabó información sobre 126 encallamientos, y se analizaron las causas, los sitios específicos, la temporada climática y los tipos de embarcaciones involucradas. Se generaron tres indicadores: presión por encallamiento, presión por año y presión por sitio. El mayor número de encallamientos ocurrió en 1925 y en el arrecife Anegada de Adentro, el más impactado en ambos periodos. Las causas más comunes de encallamiento fueron el error humano y los vientos del norte (nortes). Las embarcaciones pequeñas fueron las que más se impactaron contra los arrecifes. Los indicadores mostraron que a pesar de los avances tecnológicos, la presión por encallamientos en el PNSAV se mantiene en un nivel medio. Estos indicadores son de gran relevancia para el manejo del área ante la inminente ampliación del puerto de Veracruz, que conlleva el aumento del tráfico de embarcaciones y las posibilidades de encallamientos.

Palabras clave: encallamientos, indicadores de presión, arrecifes coralinos, áreas marinas protegidas, Sistema Arrecifal Veracruzano.

\section{INTRODUCTION}

Vessel groundings on coral reefs reduce the resilience of these ecosystems (Game et al. 2008), and the extent of their impact depends on the reef community structure and on the geomorphology and depth of the site (Connell 1978, 1997; Hughes 1989; Karlson and Hurd 1993). The damages to these ecosystems are mainly caused by vessels making bottom contact, propeller wash, and cable-dragging during salvage and refloating operations (Gittings et al. 1993). Vessel groundings fragment the coral systems and affect the genotypic diversity of a population (Chávez-Romo et al. 2013). Moreover, as these incidents may result in spills of substances into the sea, it is important to investigate them in order to monitor the health of these ecosystems (Piatt and Ford 1996, Chabanet et al. 2005).

The perceptible effects of vessel groundings vary according to the frequency of these disturbances, the ecological

\section{INTRODUCCIÓN}

Los encallamientos en los arrecifes coralinos reducen la resiliencia de estos ecosistemas (Game et al. 2008), y el nivel de impacto que tienen sobre ellos depende de la estructura de las comunidades, la geomorfología del sitio y la profundidad de la zona arrecifal (Connell 1978, 1997; Hughes 1989, Karlson y Hurd 1993). Los daños a estos ecosistemas son causados principalmente por el contacto de las embarcaciones con el fondo arrecifal, el lavado de propela y el arrastre de cables durante las operaciones de salvamento y reflotamiento (Gittings et al. 1993). Los encallamientos fragmentan los sistemas coralinos y tienen efectos en la diversidad genotípica de una población (Chávez-Romo et al. 2013). Además, estos eventos conllevan potenciales derrames de sustancias al mar, por lo cual su estudio es relevante para monitorear la salud de estos ecosistemas (Piatt y Ford 1996, Chabanet et al. 2005). 
history of the site (disturbance chronology), and the temporal and spatial scales at which they are studied (Chabanet et al. 2005, Schroeder et al. 2008). Yet despite the great threat that groundings pose to coral ecosystems, few studies have addressed the environmental and human factors associated with their occurrence.

The Parque Nacional Sistema Arrecifal Veracruzano (Veracruz Reef System National Park, PNSAV) (Veracruz, Mexico) is the largest reef system in the central Gulf of Mexico (Tunnell 1992, Spalding et al. 2001), and forms part of the reef corridor of the southwestern Gulf of Mexico (Ortiz-Lozano et al. 2013, fig. 1). The reef system is composed of 27 reef structures, four of which are fringing reefs and the rest are platform reefs. It provides important ecosystem services, such as food supply, cultural benefits, and the regulation of atmospheric phenomena (Reyna-González et al. 2014); nonetheless, it has been severely impacted by human activities.
Los efectos perceptibles de los encallamientos varían de acuerdo con la frecuencia de estos disturbios, el historial ecológico del sitio (cronología de perturbaciones) y las escalas temporales y espaciales bajo las cuales se estudien (Chabanet et al. 2005, Schroeder et al. 2008). Si bien este tipo de amenazas a los sistemas coralinos es importante, son pocos los estudios dirigidos a entender los factores ambientales y humanos asociados a su ocurrencia.

El Parque Nacional Sistema Arrecifal Veracruzano (PNSAV) (Veracruz, México) representa el sistema arrecifal de mayor tamaño de la región centro del golfo de México (Tunnell 1992, Spalding et al. 2001), y forma parte del corredor arrecifal del suroeste del golfo de México (Ortiz-Lozano et al. 2013, fig. 1). El Sistema Arrecifal Veracruzano está compuesto por 27 estructuras arrecifales, de las cuales cuatro son de tipo bordeante y el resto son de plataforma. Es considerado como un proveedor importante de servicios ambientales, tales como la provisión de alimento, el alto valor cultural

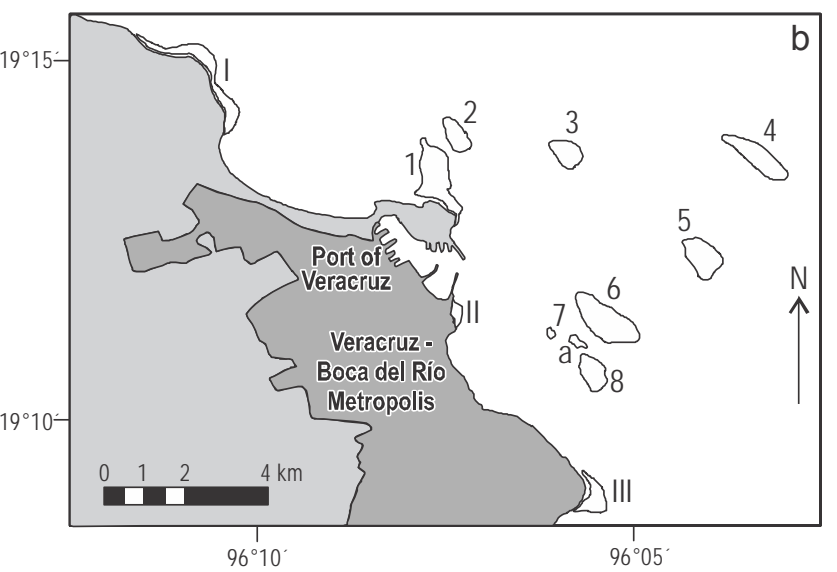

Platform Reefs Emerged
1. Gallega
2. Galleguilla
3. Blanquilla
4. Anegada de Adentro
5. Verde
6. Pájaros
7. Mersey
8. Sacrificios
9. Anegada de Afuera
10. Topatillo
11. Santiaguillo
12. Anegadilla
13. De Enmedio
14. Polo
15. Los Bajitos
16. Chopas
17. Blanca
18. Rizo
19. Cabezo

Platform Reefs Submerged a. Terranova b. La Palma

c. Sargazo

d. Periférico

Fringing Reefs

I. Punta Gorda

II. Hornos

III. Ingenieros

IV. Giote
19. Cabezo

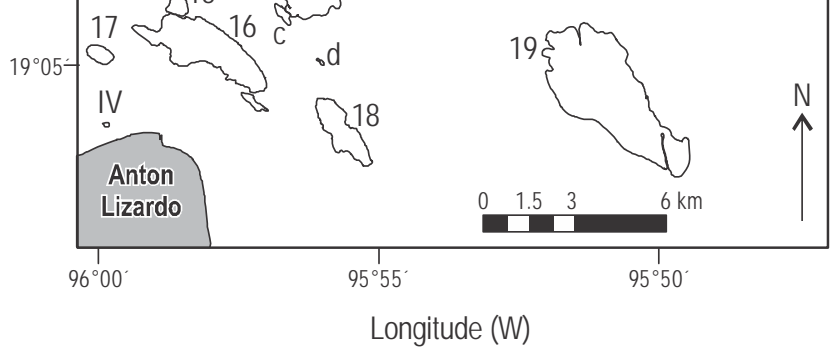

Figure 1. (a) Veracruz Reef System National Park. (b) Northern reefs. (c) Southern reefs. Figure taken and modified from Ortiz-Lozano et al. (2013).

Figura 1. (a) Parque Nacional Sistema Arrecifal Veracruzano. (b) Arrecifes del norte. (c) Arrecifes del sur. Figura tomada y modificada de Ortiz-Lozano et al. (2013). 
Of the 17 environmental problems recorded for the PNSAV (Ortiz-Lozano 2012), those associated with the Veracruz port activities, especially the expansion of its facilities and the construction of coastal protection infrastructure, are responsible for greater loss of surface area (ValadezRocha and Ortiz-Lozano 2013). The loss of coral cover and the rupture and fragmentation of corals in PNSAV has been linked to vessel groundings (Ortiz-Lozano 2012), which have occurred since the founding of the port city of Veracruz in the 16th century; however, indicators that can guide protective and restorative actions in PNSAV are lacking (Ortiz-Lozano 2012). In view of the imminent expansion of the port facilities (Valadez-Rocha and Ortiz-Lozano 2013), the generation of such indicators would be of use to identify the factors associated with vessel groundings and the responsibility of the players involved in these accidents (Peynador and Escofet 2009), as well as the reefs requiring a more effective management strategy.

In this paper we present information on vessel groundings that occurred in PNSAV in the 20th and early 21 st centuries. This information was used to generate specific pressure indicators to assess the dynamics of these incidents in this marine protected area.

\section{MATERIALS AND METHODS}

\section{Information sources and database}

Information on vessel groundings was obtained from federal government records and by a thorough revision of newspaper articles. The main source of information was El Dictamen, a newspaper that has been edited and printed in Veracruz since 1900 . We were allowed access to the private archive and examined 22,380 issues. Information was gathered for two periods, 1902-1945 and 1970-2010, but due to restrictions imposed by the owners, it was not possible to access information for the period 1946-1969. Nonetheless, the data gathered revealed a clear trend in vessel groundings in the area. The second source of information was records from different Mexican Government departments: Ministry of Public Security (Veracruz State Government), Navy Ministry (environmental impact statements), Ministry of Transport and Communications (Port Authority), and National Commission for Protected Natural Areas (García and Nava 2006). The reports of Vargas-Hernández et al. (2003) and MAM Román-Vives (unpublished, grounding of the vessel Tlaloc Re-10, Veracruz Aquarium) were also consulted.

The information for both periods was gathered in a database. The number of vessel groundings was classifed by site, cause, season, and vessel size. The frequency of these incidents was analyzed by year and the leading causes were classified according to origin (induced or not induced by humans). Three seasons were considered: Nortes (northerly winds, January-April and November-December), rainy y la regulación de fenómenos atmosféricos (Reyna-González et al. 2014). Sin embargo, las actividades humanas han repercutido considerablemente en el estado de conservación de este sistema.

De los 17 problemas ambientales registrados para el sistema arrecifal (Ortiz-Lozano 2012), aquellos asociados con las actividades del puerto de Veracruz son los que han generado una mayor pérdida de superficie, en especial la ampliación de instalaciones portuarias y la construcción de infraestructura de protección costera (Valadez-Rocha y Ortiz-Lozano 2013). La pérdida de superficie arrecifal y la ruptura y fragmentación de corales dentro del PNSAV está asociada a los encallamientos (Ortiz-Lozano 2012), los cuales han ocurrido desde la fundación de la ciudad y puerto de Veracruz en el siglo XVI; sin embargo, no hay indicadores que permitan tener referencias para guiar las acciones en materia de protección y restauración que se realicen dentro del parque (Ortiz-Lozano 2012). Con la creación de estos indicadores, ante la inminente ampliación de las instalaciones portuarias en Veracruz (Valadez-Rocha y Ortiz-Lozano 2013), será posible identificar los factores que influyen en los encallamientos y la responsabilidad de las partes que estén involucradas en estos accidentes (Peynador y Escofet 2009), así como los arrecifes que requieran mayor atención en cuanto a medidas de manejo.

Este trabajo presenta un recuento de los encallamientos ocurridos en el PNSAV a lo largo del siglo XX y principios del siglo XXI. La información recabada permitió generar indicadores de presión que sirven como punto de referencia para evaluar la dinámica de estos accidentes en esta área protegida.

\section{MATERIALES Y MÉTODOS}

\section{Fuentes de información y base de datos}

La información sobre encallamientos se obtuvo de registros de las dependencias del gobierno federal y mediante una revisión exhaustiva de periódicos. La principal fuente de información fue el acervo hemerográfico del periódico El Dictamen, que se edita e imprime en la ciudad de Veracruz desde 1900. Los dueños de este periódico permitieron el acceso a esta hemeroteca privada y se revisaron 22,380 ejemplares. Se logró recuperar información para dos periodos: 1902-1945 y 1970-2010. Por una limitante establecida por los dueños, no fue posible acceder a la información del periodo de 1946 a 1969, pero los datos obtenidos arrojan una muestra clara de las tendencias de los encallamientos en la zona. La segunda fuente de información consistió en informes de diferentes dependencias gubernamentales como la Secretaría de Seguridad Pública (Gobierno del Estado de Veracruz), la Secretaría de Marina (Armada de México, oficios de impacto ambiental), la Secretaría de Comunicaciones y Transportes (Capitanía de Puerto) y la Comisión Nacional de Áreas Naturales Protegidas (García y Nava 2006); y en los reportes técnicos de Vargas-Hernández et al. (2003) y MAM 
Table 1. Vessel classification according to size (length) per period.

Tabla 1. Clasificación de las embarcaciones por tamaño (longitud de eslora) y por periodo.

\begin{tabular}{llll}
\hline Period & Small (3-42 m) & Medium (43-60 m) & Large (>60 m) \\
\hline $1902-1945$ & $\begin{array}{l}\text { Fishing boat, canoe, whale boat, } \\
\text { yacht, tugboat, ship, sailboat, } \\
\text { "pailebot", sloop, steamboat }\end{array}$ & Brig, coastguard & Vessel, cruise ship \\
$1970-2010$ & Boat, fishing boat, yacht, tugboat & Ship, minesweeper & $\begin{array}{l}\text { Gunboat, ferryboat, barge, sailboat, } \\
\text { catamaran, dredger, vessel }\end{array}$ \\
\hline
\end{tabular}

(June-October), and dry (May) (Salas-Pérez and GranadosBarba 2008). To analyze the number of incidents by vessel size (length), three groups were established per period (table 1).

\section{Pressure indicators}

The pressure-state-response scheme (OECD 1994) considers the interrelationships among indicators of pressure, environmental state, and social response. Human activities exert pressure on the environment and change the quality and quantity of the natural resources (state), and society responds to these changes through environmental policies. The pressure exerted on the environment can be direct (gas emissions or consumption of natural resources) or indirect (resulting from human activities that exert pressure on the immediate environment) (fig. 2).

To generate the indicators, the vessel groundings within PNSAV were assumed to have an impact (exert pressure) on the reef system and modify its state. The variables used were cause, season, reef size, vessel size, and site. Reef size was used because the larger the area, the greater the likelihood of vessel groundings. Information regarding the size of the reefs was obtained from CONANP (2007).

The grounding events considered in the analysis were those for which data regarding site, cause, season, and vessel size were available (54 had complete data and 72 had incomplete data). The indicators were created in terms of the
Román-Vives (no publicado, encallamiento del buque Tlaloc Re-10, Acuario de Veracruz).

La información para ambos periodos fue sistematizada en una base de datos. Se clasificó el número de encallamientos por sitio, causa, temporada climática y tamaño de la embarcación. La frecuencia de los encallamientos fue analizada por año. Las principales causas de estos eventos fueron divididas según su origen (inducidas o no inducidas por el hombre). Se consideraron tres temporadas climáticas: nortes (vientos del norte, enero-abril y noviembre-diciembre), lluvias (junio-octubre) y secas (mayo) (Salas-Pérez y GranadosBarba 2008). Para analizar el número de encallamientos por tamaño de embarcación, se crearon tres grupos con base en la longitud de eslora para ambos periodos (tabla 1).

\section{Indicadores de presión}

El esquema presión-estado-respuesta (OECD 1994) considera las interrelaciones entre indicadores de presión, del estado del ambiente y de respuesta social. Las actividades del ser humano ejercen presión sobre el ambiente y cambian la calidad y cantidad de los recursos naturales (estado), y la sociedad responde a estos cambios a través de políticas ambientales. La presión sobre el ambiente puede ser de manera directa (emisión de gases o consumo de recursos naturales) o indirecta (reflejando actividades humanas que dan lugar a presiones sobre el medio ambiente inmediato) (fig. 2).

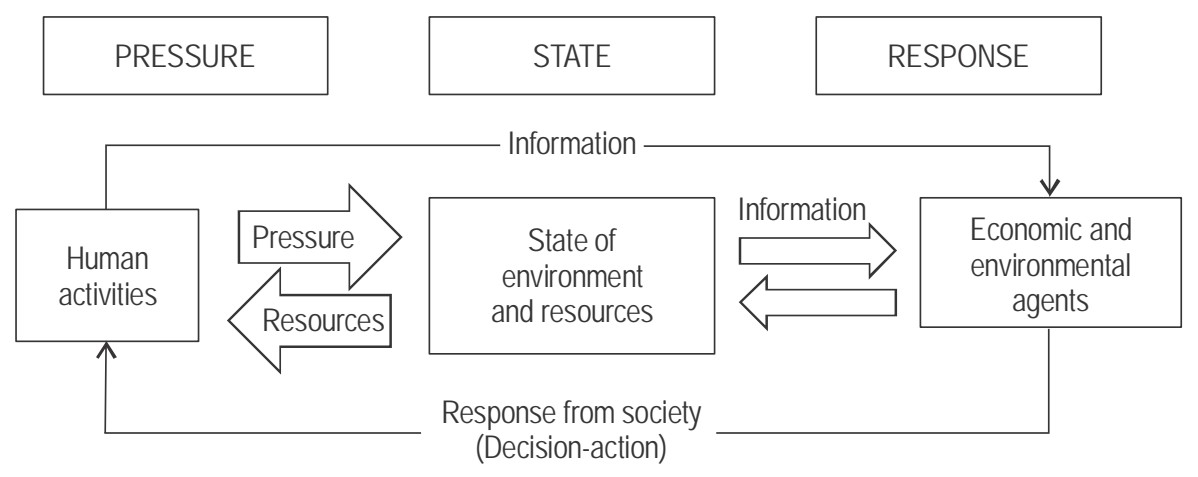

Figure 2. Flow chart of the pressure-state-response model (OECD 1999).

Figura 2. Diagrama de flujo del modelo presión-estado-respuesta (OECD 1999). 
Table 2. Weight of variables based on their frequency.

Tabla 2. Ponderación de las variables con base en su frecuencia.

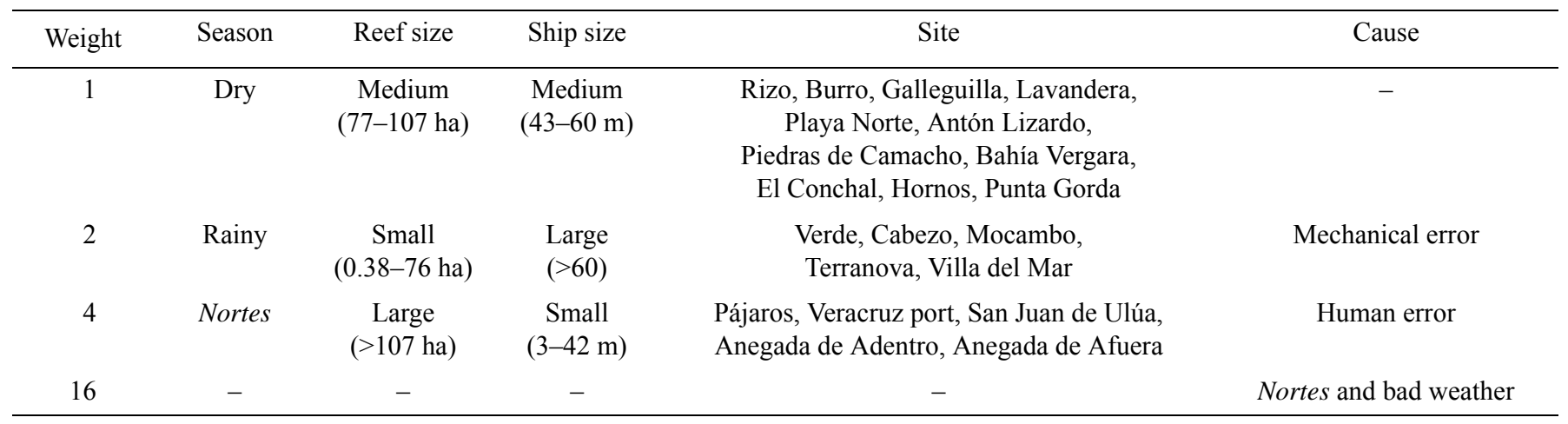

frequency of the variables of the events. Each variable was assigned a weight according to the number of times the variable occurred throughout the study period: the higher the frequency, the higher the weight value and, therefore, the pressure. A geometric scale was used for the weights (table 2).

To measure the pressure exerted by the vessel groundings, a pressure indicator (PI) was created for each event with the following equation:

$$
\mathrm{PI}=\Sigma\left(\mathrm{SEw}, \mathrm{RSw}, \mathrm{VSw}, \mathrm{SIw}, \mathrm{Cw}^{*}\right)
$$

where SEw, RSw, VSw, SIw, and $\mathrm{Cw}^{*}$ are the specific season, reef size, vessel size, site, and cause weights, respectively, for PNSAV. When the vessel grounding was attributed to more than one cause, the cause weights were added to the equation: for example, PI $=\Sigma(\mathrm{SEw}, \mathrm{RSw}, \mathrm{VSw}, \mathrm{SIw}, \mathrm{Cw} 1$, $\mathrm{Cw} 2 \ldots)$.

Based on the PI, an annual pressure indicator (API) and a site pressure indicator (SPI) were generated. The API was used to evaluate the pressure of the vessel groundings per year:

$$
\mathrm{API}[\text { year }]=\Sigma\left(\operatorname{PI}\left[\text { site }_{1}\right], \ldots, \operatorname{PI}\left[\text { site }_{n}\right]\right)
$$

Example: API[1922] $=\Sigma($ PI[Port], PI[San Juan de Ulúa]).

The SPI was used to evaluate the pressure on each particular reef edifice:

$$
\mathrm{SPI}[\text { reef }]=\Sigma\left(\mathrm{PI}\left[\text { year }_{1}\right], \ldots, \mathrm{PI}\left[\text { year }_{n}\right]\right)
$$

Example: SPI[Anegada de Afuera] = S(PI[1930], PI[1936], PI[1980], PI[1986], PI[2003]).

To determine the level of pressure exerted by the vessel groundings by year and site, all the API and SPI values were plotted separately to examine if they were normally distributed. Since they were not, four pressure level classes were defined taking as limits the inflection points of the plotted curve (table 3 ).
Para generar los indicadores, se planteó que los encallamientos dentro del PNSAV provocan un impacto (presión) sobre el sistema arrecifal y modifican su estado. Las variables utilizadas fueron causa, temporada, tamaño del arrecife, tamaño de la embarcación y sitio. La variable tamaño del arrecife se utilizó porque se consideró que a mayor superficie arrecifal, mayor probabilidad de encallamiento. La información referente al tamaño de los arrecifes se obtuvo de CONANP (2007).

Se utilizó la información de aquellos eventos que contaban con datos sobre sitio, causa, temporada climática y tamaño de la embarcación (54 registros completos, 72 registros incompletos). Los indicadores se crearon en términos de la frecuencia de las variables de los eventos. A cada variable se le asignó un ponderador de acuerdo con el número de veces que la variable se encontró presente a lo largo del periodo estudiado: a mayor frecuencia, mayor valor del ponderador y, por lo tanto, mayor presión. Se utilizó una escala geométrica para los ponderadores (tabla 2).

Para medir la presión ejercida por los encallamientos, se creó un indicador de presión por cada encallamiento (IPE) con la siguiente ecuación:

$$
\mathrm{IPE}=\Sigma\left(\mathrm{pT}, \mathrm{pTA}, \mathrm{pTE}, \mathrm{pS}, \mathrm{pC}^{*}\right)
$$

donde pT, pTA, pTE, pS y $\mathrm{pC}^{*}$ son los ponderadores de la temporada climática, el tamaño del arrecife, el tamaño de la embarcación, el sitio y la causa, respectivamente, específicos para el PNSAV. Cuando el encallamiento se debió a más de una causa, se añadieron los ponderadores de las causas a la ecuación: por ejemplo, IPE $=\Sigma(\mathrm{pT}, \mathrm{pTA}, \mathrm{pTE}, \mathrm{pS}, \mathrm{pC} 1$, $\mathrm{pC} 2 \ldots)$.

A partir del IPE, se generó el indicador de presión anual (IPA) y el indicador de presión por sitio (IPS). El IPA se utilizó para evaluar la presión de los encallamientos por cada año y se obtuvo con la siguiente ecuación:

$$
\operatorname{IPA}[\text { año }]=\Sigma\left(\operatorname{IPE}\left[\mathrm{sitio}_{1}\right], \ldots, \operatorname{IPE}\left[\text { sitio }_{n}\right]\right)
$$




\section{RESULTS}

\section{Vessel grounding behavior}

Information on 126 vessel groundings was gathered: 84 occurred between 1902 and 1945, and 42 between 1970 and 2010. Information on 102 of them was obtained from the newspaper El Dictamen, while government records were the source of information for the rest.

The frequency analysis (fig. 3) revealed that the highest number of grounding events $(29 ; 23.01 \%$ of the total) occurred in 1925. A tropical storm occurred during this same year (NOAA 2011). The second highest number (5.55\%) occurred in 1942 (fig. 3). The annual mean was one event.

The analysis of the number of vessel groundings by site (fig. 4) indicated that most accidents $(35 ; 27.55 \%$ of the total) occurred in the port. The average number of accidents per site was 3.81. Ten accidents (10\%) occurred at the Anegada de Adentro reef. Records were not obtained for Anegadilla, Gallega, Giote, and Topatillo.

Some of the documented vessel groundings occurred on reefs that have since disappeared due to the effects of port expansion activities during the 20th century (HernándezTéllez 2005, Valadez-Rocha and Ortiz-Lozano 2013). This does not mean that these reefs (e.g., El Burro, La Bandera [Lavandera], Pastelillo, Piedras de Camacho, Punta Cempoala, Laja la Visarra de Afuera, Laja de Adentro, Tecpantlayácac, Isleta de Gavias [Brea], and Bajo Aviso) disappeared because of these events.

Human error was the main cause of vessel accidents during the periods $1902-1945$ and $1970-2010$ (34.8\% and $30.8 \%$, respectively) (fig. 5). During the period 1902-1945, Nortes were the second cause of accidents, though there was only a slight difference between the human error and Nortes values (34.8\% and $33.3 \%$, respectively). Records exist of the intentional sinking of ships used for target and dynamite practice by the Mexican Navy in 1925 and 1933. During the period 1970-2010, the second cause of grounding events was mechanical failure. Failures in nautical signalling were not recorded in the late 20th century. The cause of 55 grounding events is not known.

During the period $1902-1945,64.5 \%$ of the grounding events occurred during the Nortes season (fig. 6). During the period $1970-2010,51.5 \%$ of the events occurred during the
Ejemplo: IPA[1922] $=\Sigma($ IPE[Puerto], IPE[San Juan de Ulúa])

El IPS se utilizó para evaluar la presión en cada edificio arrecifal en particular:

$$
\operatorname{IPS}[\operatorname{arrecife}]=\Sigma\left(\operatorname{IPE}\left[\mathrm{año}_{1}\right], \ldots, \operatorname{IPE}\left[\mathrm{anno}_{n}\right]\right)
$$

Ejemplo: IPS[Anegada de Afuera] $=\Sigma(\operatorname{IPE}[1930]$, IPE[1936], IPE[1980], IPE[1986], IPE[2003])

Para clasificar el nivel de presión de los encallamientos por año, todos los valores del IPA fueron graficados para analizar si presentaban una distribución normal. Dado que los datos no presentaron esta distribución, se consideraron cuatro clases tomando como límites los puntos de inflexión de la curva graficada, y estos puntos fueron llamados nivel de presión. Para clasificar el nivel de presión por sitio, se empleó la misma metodología para los valores del IPS (tabla 3).

\section{RESULTADOS}

\section{Comportamiento de los encallamientos}

Se registró un total de 126 encallamientos, de los cuales 84 ocurrieron entre 1902 y 1945 , y 42 entre 1970 y 2010. Del total de registros, 102 fueron obtenidos del periódico El Dictamen, y el resto fue obtenido de dependencias del gobierno.

El análisis de frecuencia (fig. 3) mostró que el mayor número de encallamientos (29) ocurrió en 1925, y esto comprende el $23.01 \%$ del total de los registros. En este año también se registró una tormenta tropical (NOAA 2011). El segundo registró más alto (5.55\%) se observó para 1942. La media anual fue de un encallamiento.

La relación del número de encallamientos por sitio (fig. 4) indica que la mayoría de los accidentes ocurrió en el puerto de Veracruz, donde se registraron 35 encallamientos ( $27.55 \%$ del total de los eventos). El promedio de encallamientos por sitio fue de 3.81. El arrecife Anegada de Adentro presentó 10 encallamientos $(10 \%)$. No se obtuvieron registros de encallamientos en los arrecifes Anegadilla, Gallega, Giote y Topatillo.

Algunos de los encallamientos registrados sucedieron en estructuras arrecifales que han desaparecido por efectos de

Table 3. Classification of grounding pressure level by period and site.

Tabla 3. Clasificación de los niveles de presión por encallamiento según el periodo y el sitio.

\begin{tabular}{cccc}
\hline \multicolumn{2}{c}{ Annual pressure indicator } & & \multicolumn{2}{c}{ Pressure indicator by site } \\
\cline { 1 - 3 } Range & Pressure level & Range & Pressure level \\
\hline $9-25$ & Low & $10-29$ & Low \\
$26-60$ & Medium & $30-55$ & Medium \\
$61-85$ & High & $56-101$ & High \\
$>85$ & Very high & $>101$ & Very high \\
\hline
\end{tabular}




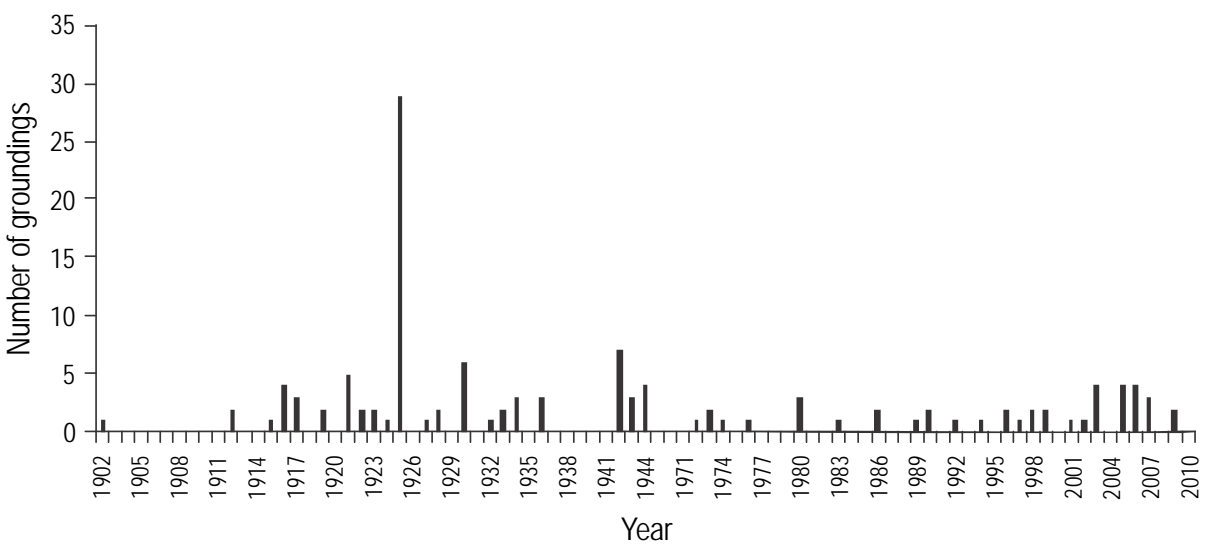

Figure 3. Number of vessel groundings per year in the Veracruz Reef System National Park.

Figura 3. Número de encallamientos por año en el Parque Nacional Sistema Arrecifal Veracruzano.

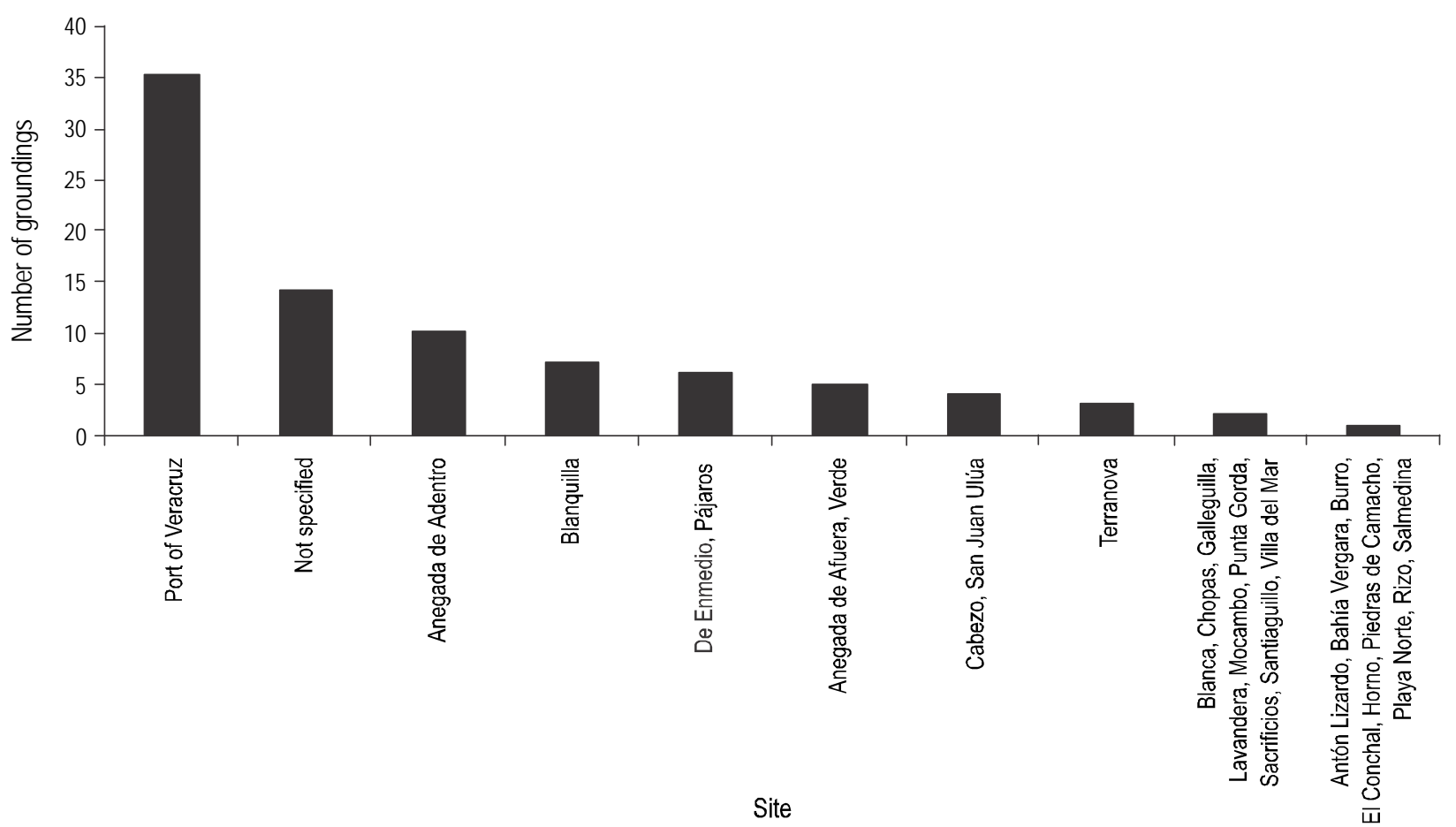

Figure 4. Number of vessel groundings per site in the Veracruz Reef System National Park during the periods 1902-1945 and 1970-2010.

Figura 4. Número de encallamientos por sitio en el Parque Nacional Sistema Arrecifal Veracruzano durante los periodos 1902-1945 y 1970-2010.

Nortes season and $45.5 \%$ during the rainy season, and only $3 \%$ during the dry season.

When the stranded vessels were grouped according to size (length), during the period 1902-1945, 59.4\% (68) were small, whereas during the period 1970-2010, 62.2\% (21) were large (fig. 7).

\section{Pressure indicators by year and site}

The API values ranged from 0 to 173 (fig. 8). The maximum value (173) corresponded to six grounding events in 1942. las obras de ampliación portuaria durante el siglo XX (Hernández-Téllez 2005 Valadez-Rocha y Ortiz-Lozano 2013). Tal es el caso de los arrecifes El Burro, La Bandera (Lavandera), Pastelillo, Piedras de Camacho, Punta Cempoala, Laja la Visarra de Afuera, Laja de Adentro, Tecpantlayácac, Isleta de Gavias o Brea, y Bajo Aviso. Esto no implica que los arrecifes hayan desaparecido a causa de los encallamientos.

La principal causa de encallamientos fue el error humano durante los periodos 1902-1945 y 1970-2010 (34.8\% y $30.8 \%$, respectivamente) (fig. 5). Los nortes fueron la segunda causa de encallamientos durante el periodo 


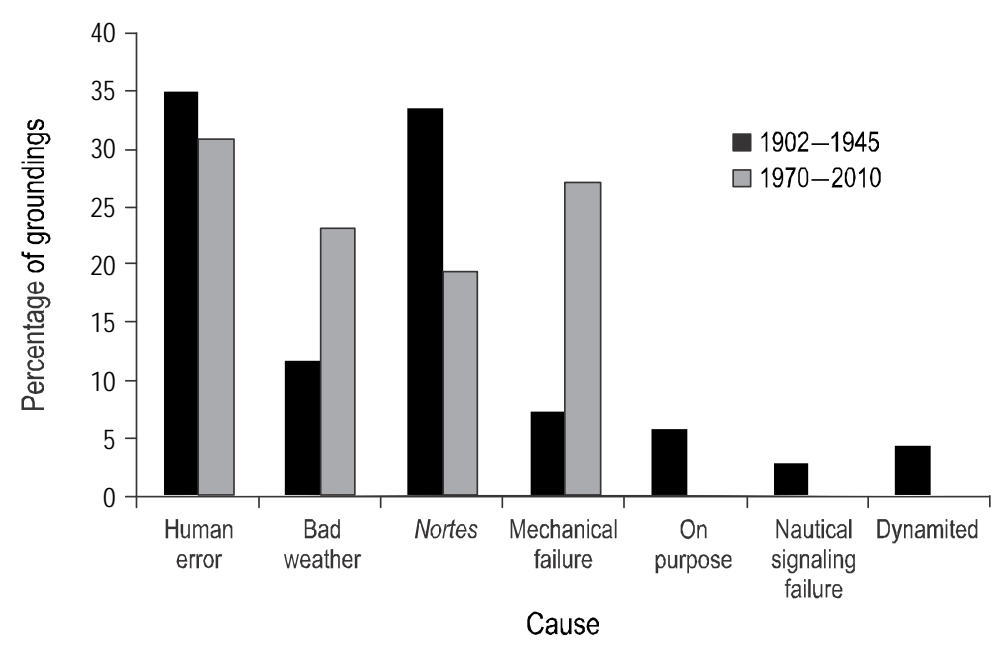

Figure 5. Percentage of vessel groundings by cause in the Veracruz Reef System National Park during the periods $1902-1945$ and 1970-2010.

Figura 5. Porcentaje de encallamientos por causa en el Parque Nacional Sistema Arrecifal Veracruzano durante los periodos 1902-1945 y 1970-2010.

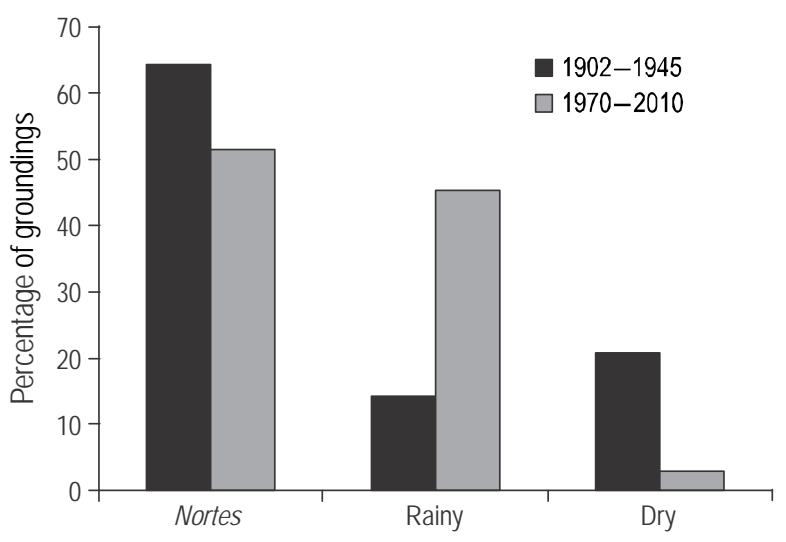

Figure 6. Percentage of vessel groundings by season in the Veracruz Reef System National Park during the periods 1902-1945 and 1970-2010.

Figura 6. Porcentaje de encallamientos por temporada en el Parque Nacional Sistema Arrecifal Veracruzano durante los periodos 1902-1945 y 1970-2010.

The SPI values (fig. 9) for Anegada de Adentro increased from the first to the second period. The values for Pájaros were high during both periods. The pressure level at Punta Gorda, Terranova, and Verde decreased from medium during the first period to low during the second. During the first period, Sacrificios, Santiaguillo, Villa del Mar, Burro, Galleguilla, Hornos, Lavandera, Mocambo, San Juan de Ulúa, Antón Lizardo, Blanquilla, and Piedras de Camacho had a low pressure level (table 4). As we were unable to obtain data for these sites for the second period, a comparison was not possible. During the second period, Anegada de Afuera, Bahía Vergara, Blanca, De Enmedio, and El Conchal had a medium pressure level.
1902-1945. La diferencia en los porcentajes entre el error humano (34.8\%) y los nortes $(33.3 \%)$ para el periodo 1902-1945 fue ligera. En 1925 y 1933 se registró el hundimiento intencional de embarcaciones que fueron utilizadas como blancos para prácticas de tiro de la Armada de México y de embarcaciones dinamitadas. Durante el periodo 1970-2010, la segunda causa de los accidentes fue la falla mecánica. No se registraron fallas en la señalización náutica a finales del siglo XX. Se desconoce la causa de 55 encallamientos.

En lo que se refiere a la temporada climática, en el periodo 1902-1945 la mayoría de los encallamientos (64.5\% del total de eventos) ocurrió en la temporada de nortes (fig. 6). Durante el periodo 1970-2010, el 51.5\% de los eventos ocurrieron en la temporada de nortes y el $45.5 \%$ en la temporada de lluvias, y solamente el $3 \%$ en la temporada de secas.

Al agrupar las embarcaciones encalladas de acuerdo con su eslora, se observó que durante el periodo 1902-1945, la mayoría $(68,59.4 \%)$ fueron chicas. Durante el periodo 1970-2010, el $62.2 \%$ de las embarcaciones (21) fueron grandes (fig. 7).

\section{Indicadores de presión por año y por sitio}

Los valores del IPA variaron de 0 a 173 (fig. 8). El valor máximo (173) correspondió a seis encallamientos ocurridos en 1942.

El IPS para el arrecife Anegada de Adentro mostró un incremento del primer al segundo periodo (fig. 9). El nivel de presión para el arrecife Pájaros se mantuvo alto . La presión en Punta Gorda, Terranova y Verde disminuyó de un nivel medio en el primer periodo a un nivel bajo en el segundo periodo. Durante el primer periodo, los sitios Sacrificios, Santiaguillo, Villa del mar, Burro, Galleguilla, Hornos, 


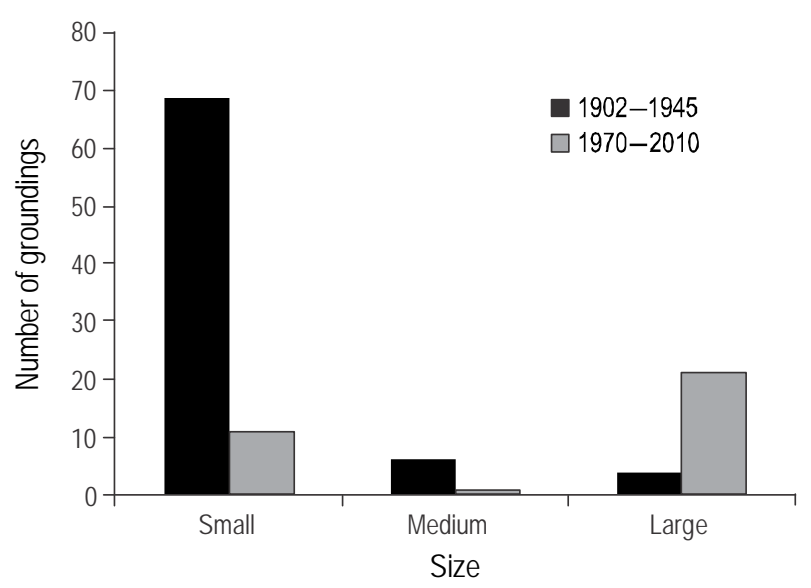

Figure 7. Number of vessel groundings in relation to vessel size in the Veracruz Reef System National Park during the periods 1902-1945 and 1970-2010.

Figura 7. Número de encallamientos con relación al tamaño de la embarcación en el Parque Nacional Sistema Arrecifal Veracruzano durante los periodos 1902-1945 y 1970-2010.

\section{DisCUSSION}

Vessel groundings have an evident impact on coral reefs (Game et al. 2008) and are an environmental problem worldwide (Lin et al. 1998, Chabanet et al. 2005, Pelot et al. 2006, Rothblum 2006, Mazaheri 2009). Studies of these types of events mainly focus on the physical effects these accidents
Lavandera, Mocambo, San Juan de Ulúa, Antón Lizardo, Blanquilla y Piedras de Camacho tuvieron un nivel de presión bajo (tabla 4). Debido a la falta de datos para el segundo periodo, estos sitios no pudieron ser comparados entre periodos. Durante el segundo periodo, el nivel de presión fue medio para los sitios Anegada de Afuera, Bahía Vergara, Blanca, De Enmedio y El Conchal.

\section{Discusión}

Los encallamientos causan uno de los impactos más evidentes en los arrecifes coralinos (Game et al. 2008) y son un problema ambiental a nivel mundial (Lin et al. 1998, Chabanet et al. 2005, Pelot et al. 2006, Rothblum 2006, Mazaheri 2009). Los estudios sobre este tipo de eventos se centran principalmente en los efectos físicos que provocan estos accidentes sobre las estructuras naturales (Burns y Knap 1989, Jackson et al. 1989, Precht et al. 2001, Riegl 2001, Negri et al. 2002) y en las acciones de restauración (Gittings et al. 1993, Lirman y Miller 2003, Rinkevich 2005). La estructura genética de las poblaciones de corales está influenciada por disturbios como los encallamientos, ya que los corales poseen estrategias reproductivas que les permiten recuperarse de este tipo de disturbios en algunos casos (Chávez-Romo et al. 2013). Hasta donde sabemos, no hay estudios que evalúen la dinámica de los encallamientos a lo largo del tiempo ni que permitan contar con referencias específicas para evaluar el éxito de las medidas tomadas para

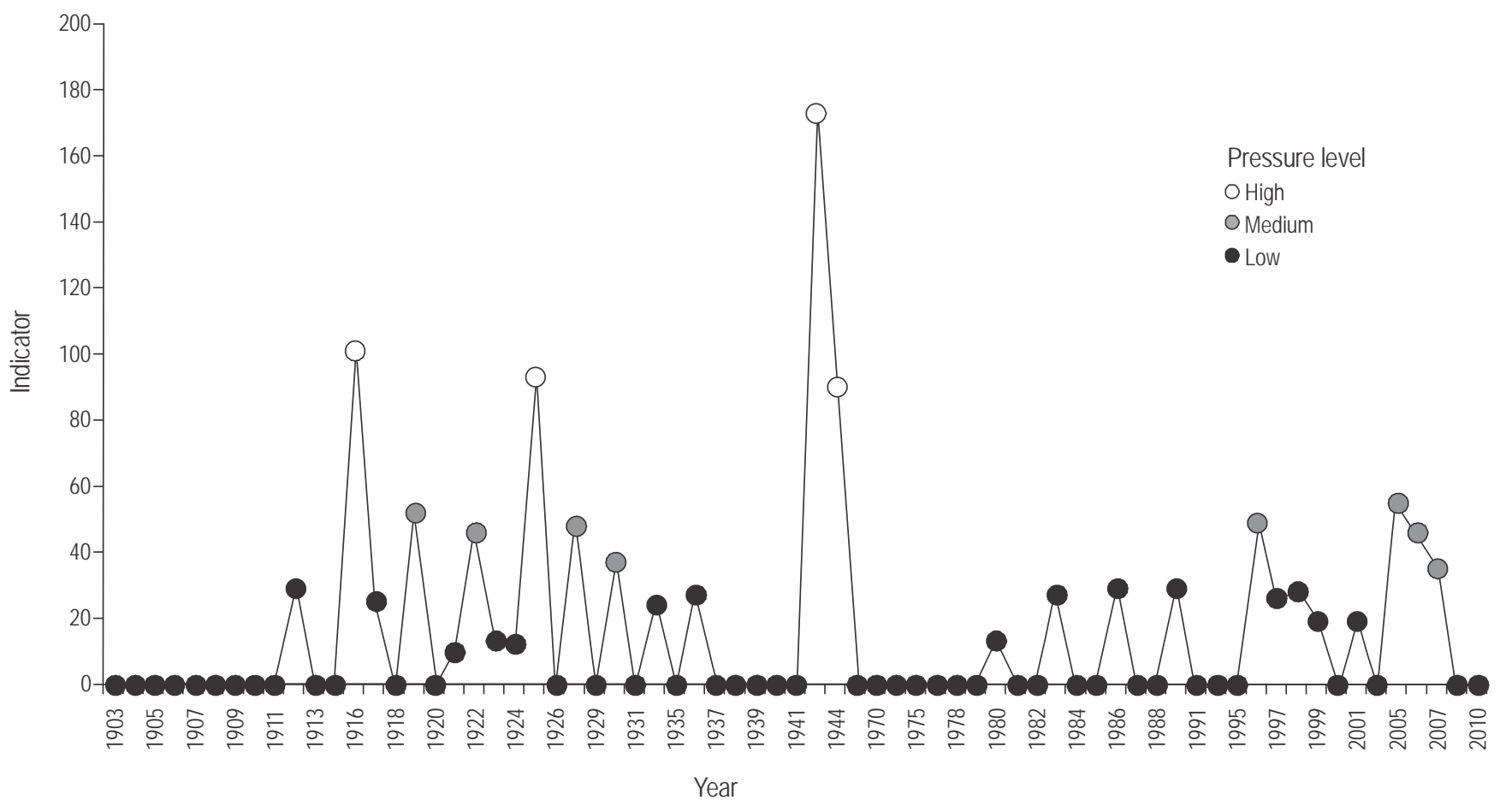

Figure 8. Trend of the annual pressure indicator.

Figura 8. Tendencia del indicador de presión anual. 


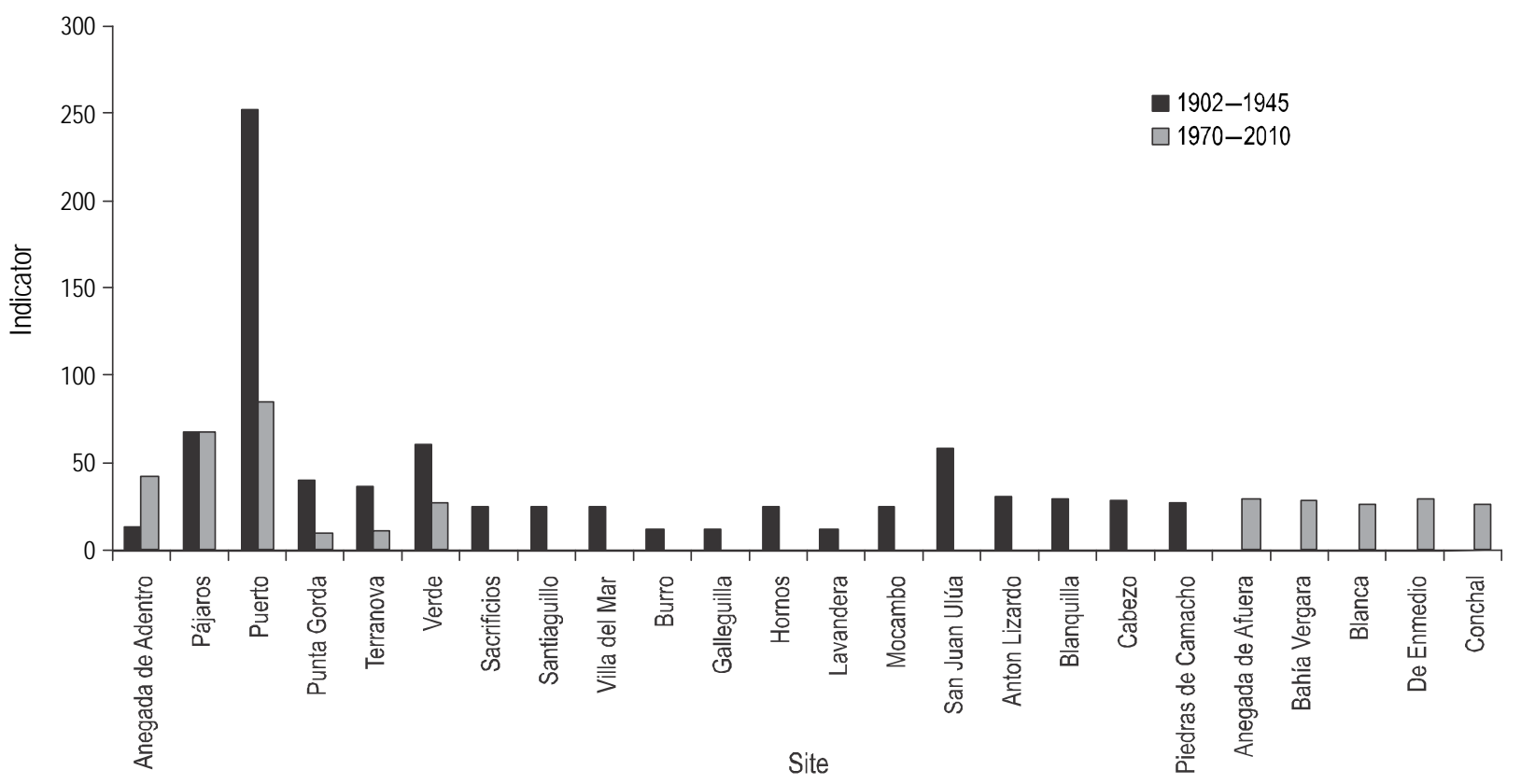

Figure 9. Comparison of the pressure indicator by site between the periods 1902-1945 and 1970-2010.

Figura 9. Comparación del indicador de presión por sitio entre los periodos 1902-1945 y 1970-2010.

have on natural structures (Burns and Knap 1989, Jackson et al. 1989, Precht et al. 2001, Riegl 2001, Negri et al. 2002) and on restoration activities (Gittings et al. 1993, Lirman and Miller 2003, Rinkevich 2005). The genetic structure of coral populations is influenced by disturbances such as vessel groundings, because corals have reproductive strategies that allow them to recover from these disturbances in some cases (Chávez-Romo et al. 2013). To the best of our knowledge, there are no studies that analyze grounding dynamics over time and that provide specific indicators to assess the success of the measures taken to prevent or decrease this type of pressure on coral reefs.

The present study is based on historical data and serves as a point of reference to evaluate the effectiveness of the measures implemented to prevent vessel groundings in PNSAV. These events occur regularly and will likely increase with the expansion of the port of Veracruz (Siemens et al. 2006, Valadez-Rocha and Ortiz-Lozano 2013). The information presented here can be used to determine whether the accidents are due to vessel maneuvers or climate events, and thus to identify the civil responsibility of those involved in the groundings and establish the compensations for possible damages (Peynador and Escofet 2009). Moreover, it will be useful for evaluating the actions of the actors involved in the use, management, and protection of PNSAV, such as establishing vessel anchoring sites and the traffic lanes for vessels entering the port.

It is reasonable to assume that the technological advances made in the past decades, both in vessel operations and the traffic control systems used by port authorities, would have evitar o disminuir este tipo de presión sobre los arrecifes coralinos.

El presente estudio se basa en datos históricos y sirve como punto de referencia para evaluar la efectividad de las medidas de protección en materia de encallamientos en el PNSAV. Estos eventos son hechos regulares y de gran trascendencia para esta área protegida si se considera el crecimiento del puerto de Veracruz y su ciudad adyacente (Siemens et al. 2006, Valadez-Rocha y Ortiz-Lozano 2013). La información aquí presentada es una herramienta esencial para identificar la responsabilidad civil de las partes implicadas en los encallamientos y puede ser una referencia para cotizar las compensaciones de posibles daños (Peynador y Escofet 2009), ya que permite identificar si los accidentes se deben a las maniobras de las embarcaciones o a eventos climáticos. Además, es un insumo útil para evaluar las acciones de los actores involucrados en el uso, manejo y protección del PNSAV, como el establecimiento de sitios para el fondeo de embarcaciones y la relevancia de las rutas de ingreso a las instalaciones portuarias.

Podría pensarse que los avances tecnológicos de las últimas décadas, tanto en la operación de las embarcaciones como en el control de tráfico por las capitanías de puerto, han tenido un impacto positivo en la disminución de encallamientos; sin embargo, el error humano es la causa principal de accidentes de tráfico marítimo (entre el $43 \%$ y $96 \%$, Hänninen y Kujala 2009) en el mundo (Brown y Haugene 1998, Rothblum 2006, Mazaheri 2009). Esto es consistente con lo observado en el PNSAV, donde más de la mitad de los encallamientos ocurrieron por errores humanos. Por otro 
Hayasaka-Ramírez and Ortiz-Lozano: Vessel groundings on coral reefs

Table 4. Pressure indicator and level by site for the periods 1902-1945 and 1970-2010.

Tabla 4. Indicador y nivel de presión por sitio en los periodos 1904-1945 y 1970-2010.

\begin{tabular}{|c|c|c|c|c|c|}
\hline \multicolumn{3}{|c|}{$1902-1945$} & \multicolumn{3}{|c|}{$1970-2010$} \\
\hline Anegada de Adentro & 13 & Low & Anegada de Adentro & 42 & Medium \\
\hline Pájaros & 67 & High & Pájaros & 67 & High \\
\hline Veracruz port & 253 & Very high & Veracruz port & 85 & High \\
\hline Punta Gorda & 40 & Medium & Punta Gorda & 9 & Low \\
\hline Verde & 60 & Medium & Verde & 27 & Low \\
\hline Sacrificios & 24 & Low & Anegada de Afuera & 29 & Medium \\
\hline Santiaguillo & 25 & Low & Bahía Vergara & 28 & Medium \\
\hline Villa del Mar & 25 & Low & Blanca & 26 & Medium \\
\hline Lavandera & 12 & Low & & & \\
\hline Mocambo & 25 & Low & & & \\
\hline San Juan de Ulúa & 58 & Medium & & & \\
\hline Antón Lizardo & 30 & Medium & & & \\
\hline Blanquilla & 29 & Medium & & & \\
\hline Cabezo & 28 & Medium & & & \\
\hline Piedras de Camacho & 27 & Medium & & & \\
\hline
\end{tabular}

had a positive impact on the number of vessel groundings; however, human error remains the main cause of maritime traffic accidents (between $43 \%$ and $96 \%$, Hänninen and Kujala 2009) in the world (Brown and Haugene 1998, Rothblum 2006, Mazaheri 2009). This is consistent with that observed at PNSAV, where more than half of the groundings were caused by human error. On the other hand, at PNSAV $27 \%$ of the accidents were due to mechanical failure, differing from that observed elsewhere. For example, in the Gulf of Finland, only $9.4 \%$ of the accidents were attributed to mechanical failure (Hänninen and Kujala 2009). According to Brown and Haugene (1998), the risk of vessel groundings due to human error can be reduced by $99 \%$ with the implementation of better management and operational measures for cargo vessels.

The Maritime Traffic Decree for the port of Veracruz (Diario Oficial de la Federación, 17 July 1998, Mexico) establishes the rules of entry into the port. The average vessel grounding rate since the promulgation of the decree in 1998 is two per year, higher than the average for previous years, and the pressure indicators have remained at a medium level. The increase in maritime traffic needs to be considered in the continuous assessment of these indicators. Compared with the 1980s and 1990s, the number of cargo vessels entering the port doubled (SCT 2010), but it was not possible to integrate this information into our analysis because there are no port traffic statistics for both study periods. From 1994 to lado, el 27\% de los encallamientos en el PNSAV ocurrió por fallas mecánicas. Esta cifra difiere de lo registrado para otros lugares como, por ejemplo, el golfo de Finlandia, donde sólo el $9.4 \%$ de los accidentes fueron causados por fallas mecánicas (Hänninen y Kujala 2009). Brown y Haugene (1998) indicaron que la probabilidad de riesgo de encallamiento por errores humanos puede reducirse en un $99 \%$ cuando se implementan mejores medidas en el manejo y operación de los buques cargueros.

El Decreto de Tráfico Marítimo para el puerto de Veracruz (Diario Oficial de la Federación, 17 de julio de 1998, México), establece las reglas de acceso al Puerto. Sin embargo, la tasa promedio de encallamientos a partir de la promulgación del decreto fue de casi dos encallamientos por año, cifra mayor que el promedio para los años anteriores, $y$ los indicadores de presión se han mantenido en un nivel medio. Para el seguimiento de estos indicadores, debe considerarse el aumento de tráfico marítimo. Comparando con las décadas de 1980 y 1990, el número de barcos cargueros que arribaron al puerto se duplicó (SCT 2010), pero en el presente trabajo no fue posible integrar esta información al análisis porque no existen estadísticas de tráfico portuario para ambos periodos de estudio. De 1994 a la fecha, el tráfico marítimo que ingresa al puerto de Veracruz se ha mantenido por arriba de 1200 barcos al año, y el registro máximo es de 1800 barcos. 
date, more than 1200 vessels have entered the port per year, and the maximum recorded was 1800 vessels.

On average, 11 hurricanes and tropical storms occurred per decade between 1900 and 1919, whereas 26 hurricanes occurred during the 1920s and 1930s (NOAA 2011). According to the International Maritime Organization, $30 \%$ of the vessels worldwide were lost over five years as a result of adverse weather conditions (Pelot et al. 2006). This information is in agreement with the information obtained for PNSAV, where $35 \%$ of all the vessel groundings were weather-related.

The PNSAV was designated a protected natural area in 1992 (Diario Oficial de la Federación, 24 August 1992, Mexico), and an increased awareness of the risk of shipping accidents would be expected. Both the API and SPI values have remained at low and medium levels after the decree (fig. 8), and this could be a reflection of the low effectiveness of the management measures implemented by the authorities of the protected area and the port authorities to address this problem. This ineffectiveness acquires relevance and pertinance since the planned expansion of the port of Veracruz over the next 15 years contemplates greater vessel traffic in the PNSAV. Thus, having specific indicators associated with vessel groundings for the management and conservation of the area is important for the future relationship between the national park and port.

The information generated in this study can serve as a point of reference for the park authorities to initiate restoration activities in PNSAV in order to address the effects of vessel groundings. To reduce the number of these events, however, a coordinated strategy with the naval authorities would be needed.

\section{ACKNOWLEDGMENTS}

This study forms part of the project entitled "Influencia Histórica de la Ciudad y Puerto de Veracruz sobre el Sistema Arrecifal Veracruzano" (327202010176 DGI-ICMP-UV). The National Council for Science and Technology (CONACYT, Mexico) partially funded this study (project No. 89526) and awarded a scholarship to the first author. We thank Ileana Espejel for her collaboration.

English translation by Christine Harris.

\section{REFERENCES}

Brown A, Haugene B. 1998. Assessing the impact of management and organizational factors on the risk of tanker grounding. 8th International Offshore and Polar Engineering Conference, 24-29 May, Quebec, Canada, pp. 469-476.

Burns KA, Knap AH. 1989. The Bahia Las Minas oil spill: Hydrocarbon uptake by reef building corals. Mar. Pollut. Bull. 20: 391-398. http://dx.doi.org/10.1016/0025-326X(89)90317-2

Chabanet P, Adjeroud M, Andréfouet S, Bozec YM, Ferraris J, García-Charton JA, Schrimm M. 2005. Human-induced physical disturbances and their indicators on coral reef habitats:
En promedio, ocurrieron 11 huracanes y tormentas tropicales en conjunto por década entre 1900 y 1919 (NOAA 2011). En las décadas de 1920 y 1930, el número de huracanes y tormentas fue de 26. La Organización Marítima Internacional indicó que durante cinco años, el 30\% de la pérdida de embarcaciones a nivel mundial ocurrió en condiciones climáticas adversas (Pelot et al. 2006). Esta información es congruente con lo que ocurre en el PNSAV, ya que el $35 \%$ de los encallamientos totales sucedieron por causas climatológicas.

El PNSAV fue decretado área natural protegida en 1992 (Diario Oficial de la Federación, 24 de agosto de 1992, México), lo cual supondría una mejor atención a los accidentes marítimos. Tanto los valores del IPS como los del IPA se han mantenido en niveles bajos y medios después del decreto (fig. 8), y esto puede reflejar una poca efectividad en las medidas de manejo por parte de la autoridad del área protegida y la capitanía de puerto para abatir está problemática. Esto adquiere gran relevancia y pertinencia, ya que el proyecto de ampliación del puerto de Veracruz, a efectuarse durante los próximos 15 años, plantea el ingreso de más embarcaciones de alto calado al sistema arrecifal. Por tanto, contar con indicadores específicos sobre la importancia de los encallamientos para el manejo y conservación del área es parte fundamental de la futura relación entre las actividades portuarias y este parque nacional.

Es necesario recalcar que la información generada en este estudio puede servir como punto de referencia para el inicio de actividades de restauración en el PNSAV por parte de las autoridades del parque para atender los efectos de los encallamientos. Para reducir el número de eventos, se necesitaría establecer una estrategia con las autoridades navales.

\section{AgRADECIMIENTOS}

Este trabajo es parte del proyecto Influencia histórica de la Ciudad y Puerto de Veracruz sobre el Sistema Arrecifal Veracruzano (327202010176 DGI-ICMP-UV). El Consejo Nacional de Ciencia y Tecnología (CONACYT) financió parcialmente este estudio (proyecto No. 89526) y otorgó una beca de maestría al primer autor. Agradecemos la colaboración de Ileana Espejel.

A multi-scale approach. Aquat. Living Resour. 18: 215-230. http://dx.doi.org/10.1051/alr:2005028

Chávez-Romo HE, Paz-García DA, Correa-Sandoval F, ReyesBonilla H, López-Pérez RA, Medina-Rosas P. 2013. Difference in reproductive strategies of two scleractinian corals (branching vs massive) along the west coast of Mexico. Cienc. Mar. 39: 387-400.

http://dx.doi.org/10.7773/cm.v39i4.2272

[CONANP] Comisión Nacional de Áreas Naturales Protegidas. 2007. Objetivos Estratégicos. Available at: http:// www.conanp.gob.mx/quienes_somos/ objetivos_estrategicos.php [cited March 2011]. 
Connell JH. 1978. Diversity in tropical rain forests and coral reefs. Science 199: 1302-1310.

Connell JH. 1997. Disturbance and recovery of coral assemblages. Proc. 8th Int. Coral Reef Symp., Panama, 1: 9-22. http://dx.doi.org/10.1007/s003380050246.

Game ET, McDonald-Madden E, Puotinen ML, Possingham HP. 2008. Should we protect the strong or the weak? Risk, resilience, and the selection of marine protected areas. Conserv. Biol. 22: 1619-1629. http://dx.doi.org/10.1111/j.1523-1739.2008.01037.x

García M, Nava G. 2006. Guía de procedimientos en eventos de impacto en los arrecifes coralinos. OCEANUS, CONANP, Mexico, $28 \mathrm{pp}$.

Gittings SR, Bright TJ, Hagman DK. 1993. The M/V Wellwood and other large vessel groundings: Coral reef damage and recovery. In: Ginsburg RN (ed.), Global Aspects of Coral Reefs: Health, hazard, and history. Univ. of Miami, Miami, Florida, pp. 174-180. Available at http://www.aoml.noaa.gov/general/ lib/CREWS/mlrf 11.pdf

Hänninen M, Kujala P. 2009. The effects of causation probability on the ship collision statistics in the Gulf of Finland. 8th International Navigational Symposium on Marine Navigation and Safety of SeaTtransportation, TRANSNAV, 17-19 June, Gydnia.

Hernández-Téllez J. 2005. Naufragios de las flotas de la Nueva España en los arrecifes veracruzanos, durante el siglo XVI. Diario de Campo (31): 60-67.

Hughes TP. 1989. Community structure and diversity of coral reefs: The role of history. Ecology 70: 275-279.

Jackson JBC, Cubit JD, Keller BD, Batista V, Burns K, Caffey HM, Caldwell RL, Garrity SD, Getter CD, Gonzalez C, Guzman HM, Kaufmann KW, Knap AH, Levings SC, Marshall MJ, Steger R, Thompson RC, Weil E. 1989. Ecological effects of a major oil spill on Panamanian coastal marine communities. Science 243: $37-44$.

Karlson RH, Hurd LE. 1993. Disturbances, coral reef communities and changing ecological paradigms. Coral Reefs 12: 117-125. http://dx.doi.org/10.1007/BF00334469

Lin S, Kite-Powell HL, Patrikalakis NM. 1998. Physical risk analysis of ship grounding. Massachusetts Institute of Technology, Massachusetts, USA.

Lirman D, Miller MW. 2003. Modeling and monitoring tools to assess recovery status and convergence rates between restored and undisturbed coral reef habitats. Restor. Ecol. 11: 448-456. http://dx.doi.org/10.1046/j.1526-100X.2003.rec0286.x

Mazaheri A. 2009. Probabilistic Modeling of Ship Grounding. Helsinki University of Technology, Espoo, Finland, 63 pp.

Negri AP, Smith LD, Webster NS, Heyward AJ. 2002. Understanding ship-grounding impacts on coral reef: Potential effects of anti-foulant paint contamination on coral recruitment. Mar. Pollut. Bull. 4: 111-117. http://dx.doi.org/10.1016/S0025-326X(01)00128-X

[NOAA] National Oceanic and Atmospheric Administration. 2011. Historical Hurricane Tracks. Available at http://www.csc.noaa. gov/hurricanes/\# [cited March 2011].

[OECD] Organisation of Economic Co-operation and Development. 1994. Environmental indicators: OECD core set. Report from Secretary General of the OECD, Paris, France, $160 \mathrm{pp}$.

Ortiz-Lozano LD. 2012. Identification of priority conservation actions in marine protected areas: Using a causal networks approach. Ocean Coast. Manage. 55: 74-83. http://dx.doi.org/10.1016/j.ocecoaman.2011.10.013

Ortiz-Lozano L, Perez-España H, Granados-Barba A, GonzálezGándara C, Gutiérrez-Velázquez A, Martos J. 2013. The Reef Corridor of the Southwest Gulf of Mexico: Challenges for its management and conservation. Ocean Coast. Manage. 86: $22-32$.

http://dx.doi.org/10.1016/j.ocecoaman.2013.10.006

Pelot R, Hilliard C, Mukesh MD, Deacoff C, Wootton D, Moyst H. 2006. Cruise ship activity and risk analysis for improved SAR Response Planning. Maritime activity and risk investigation network. MARIN Rep. \#2006-03, 82 pp.

Peynador C, Escofet A. 2009. An ad hoc procedure for the environmental assessment of ship grounding at Todos Santos Bay (Baja California, Mexico): Lessons and perspectives. In: Halley GT, Fridian YT (eds.), Environmental Impact Assessments. Nova Science Publishers, New York, pp. 193-224.

Piatt JF, Ford RG. 1996. How many birds were killed by the Exxon Valdez oil spill? Am. Fish. Soc. Symp. 18: 712-719.

Precht WF, Aronson RB, Swanson DW. 2001. Improving scientific decision-making in the restoration of ship-grounding sites on coral reefs. Bull. Mar. Sci. 69: 1001-1012.

Reyna-González PC, Bello-Pineda J, Ortíz-Lozano L, Pérez-España $\mathrm{H}$, Arceo P, Brenner J, 2014. Incorporating expert knowledge for development spatial modeling in assessing ecosystem services provided by coral reefs: A tool for decision-making. Rev. Biol. Mar. Oceanogr. 49: 279-292. http://dx.doi.org/10.4067/S0718-19572014000200008

Riegl B. 2001. Degradation of reef structure, coral and fish communities in the Red Sea by ship groundings and dynamite fisheries. Bull. Mar. Sci. 69: 595-611.

Rinkevich B. 2005. Conservation of coral reefs through active restoration measures. Recent approaches and last decade progress. Environ. Sci .Technol. 39: 4333-4342. http://dx.doi.org/10.1021/es0482583

Rothblum MA. 2006. Human error and marine safety. Vol. 4. In: US Coast Guard Risk-Based Decision-Making Guidelines. US Coast Guard Research and Development Center, 9 pp.

Salas-Pérez JJ, Granados-Barba A. 2008. Oceanographic characterization of the Veracruz Reef System. Atmósfera 21: 281-301.

Schroeder RE, Green AL, De Martini EE, Kenyon JC. 2008. Longterm effects of a ship-grounding on coral reef fish assemblages at Rose Atoll, American Samoa. Bull. Mar. Sci. 82: 345-364.

SCT, Secretaría de Comunicación y Transportes. 2010. Relación de accidentes/incidentes marítimos/portuarios ocurridos del 1998 al 2010 en el estado de Veracruz. Veracruz, México, 2 pp.

Siemens AH, Moreno-Casasola P, Sarabia-Bueno C. 2006. The metabolization of dunes and wetlands by the city of Veracruz, Mexico. J. Latin Am. Geogr. 5: 8-29. http://dx.doi.org/10.1353/lag.2006.0010

Spalding M, Ravilious C, Green EP. 2001. World Atlas of Coral Reefs. Prepared at the UNEP World Conservation Monitoring Center, University of California Press, Berkeley, CA, 424 pp.

Tunnell JW. 1992. Natural versus human impacts to southern Gulf of Mexico. Coral Reef Resources. Proc. 7th International Coral Reef Symposium, Guam, Micronesia, pp. 300-306.

Valadez-Rocha V, Ortiz-Lozano L. 2013. Spatial and temporal effects of port facilities expansion on the surface area of shallow coral reefs. Environ. Manage. 52: 250-260. http://dx.doi.org/10.1007/s00267-013-0098-5

Vargas-Hernández JM, Lozano-Aburto MA, Ortega-Navarro R, Román-Vives MAM. 2003. Evaluación del impacto de un barco camaronero en el "Arrecife Cabezo". Parque Nacional "Sistema Arrecifal Veracruzano". Centro de Ecología y Pesquerías, Universidad Veracruzana, Acuario de Veracruz. Tech. Rep.

Received August 2014, accepted November 2014. 